\title{
EFFECT OF NPK FERTILIZER AND INTERVAL MANAGEMENT ON THE CHEMICAL PROPERITIES OF COASTAL PLAIN SANDS OF AKPABUYO, NIGERIA
}

\author{
W. UBI, M. W. UBI AND A. U. AKPANIDIOK \\ (Received 9 July 2012; Revision Accepted 22 February 2013)
}

\begin{abstract}
Investigation of the chemical properties of the coastal plain soils treated with NPK 20:10:10 fertilizer (NPK) at the rate of $0,60,90$ and $120 \mathrm{~kg} \mathrm{ha}^{-1}$ and observed at intervals of 3,6,9 and 12 months was carried out from March 2009 to 2010 at Akpabuyo, Cross River State, Nigeria. The experiment comprises of four fertilizer rates and four management intervals fitted into a Latin square design. The soils $\mathrm{pH}$ value increased consistently from 3 to $12 \mathrm{months}$. Mean values of organic matter decreased with increase in profile depth from $2.12-1.34 \mathrm{~g} \mathrm{~kg}^{-1}$. The distribution of $\mathrm{N}$ from the top soil down the profile increased consistently from 3 to 12 months. The mean value of $\mathrm{N}$ from the top soil was $0.82 \%$. Exceeding $0.2 \%$, the critical value and was more than the mean values obtained in the sub-surface soil. The mean value of $P\left(33 \mathrm{mgkg}^{-1}\right)$ during the 9 months interval was significantly $(P<0.05)$ higher than all other sampling periods. There was vertical and horizontal loading of $P$ which lead to higher available $P$ at the surface in soil depths of $0-15$ and $15-30 \mathrm{~cm}$ than $30-40 \mathrm{~cm}$ and $40-50 \mathrm{~cm}$. Levels of $\mathrm{Ca}$ increased slightly with sampling interval but decreased down the profile. The soils were also characterized as follows: strongly acid (pH $5.1-5.3)$, exchangeable Mg. (> 0.5 $\mathrm{cmol} \mathrm{kg}{ }^{-1}$ ), low contents of $\mathrm{K}$ and $\mathrm{Na}$ as well as high exchangeable Al. levels $\left(>4.0 \mathrm{cmol} \mathrm{kg}^{-1}\right)$ and cation exchange capacity $\left(22-36 \mathrm{cmol} \mathrm{kg}^{-1}\right)$ The application of $90 \mathrm{~kg} / \mathrm{ha}^{-1} \mathrm{NPK}$ fertilizer during the 9 months interval gave highest values of N.P, $\mathrm{Ca}$ and $\mathrm{Mg}$ under the condition of the experiment, indicating that these elements will not be deficient in these soils. Equally, the CEC, organic matter and base saturation had their advantage in the 9 months interval where $90 \mathrm{~kg}$ " was applied. This is cost effective and could be used to improve crop production in Akpabuyo, Nigeria.
\end{abstract}

KEY WORD: Chemical Properties, NPK Fertilization, Management Intervals, Coastal Plain Sands.

\section{INTRODUCTION}

To increase crop performance, there is always need to establish relationships between soil chemical properties and soil capacity to produce food crops. The soils capacity and capability to produce crops is indeed the basis of yield predictions and could be considered as the most useful expression of soil productivity (Enwesor, 1981). Yield and crop performances are however closely correlated with soil condition.

FAO (1986) reported that coastal plain sands cover an area of $480 \mathrm{~km}^{2}$ in Cross River, $3,470.32 \mathrm{~km}^{2}$ in Bendel State, $42.20 \mathrm{~km}^{2}$ in Lagos State, $213.16 \mathrm{~km}^{2}$ inAkwa lbom State, $12.18 \mathrm{~km}^{2}$ in Ogun State, $40.62 \mathrm{~km}^{2}$ in Ondo State; and $5.435 .92 \mathrm{~km}^{2}$ in River State. In Cross River State, coastal plain soils are found mostly in Akpbuayo, Bakassi, Calabar and Odukpani Local Government Areas.

Coastal plain soils have high agricultural potentials because of their moderate inherent fertility and availability of water during the dry season. In crop production and land use, the evaluation of soils' chemical properties is important because properties such as $\mathrm{pH}$, Organic matter, Nitrogen, Phosphorus
Exchangeable bases, Cation Exchange Capacity and Base saturation affect plant growth and development (Enwezor 1981).

Coastal plain soils are underlain by massive deposits of limestone, with kaolinite as dominant clay, $\mathrm{pH}$ of 5.0 C.E.C of $13.10 \mathrm{cmol}(+) \mathrm{kg}^{-1}$ and based saturation of about 13\% (Enwesor 1981). The soils are acidic due to the parent material from which they are formed; they are low in nutrient status $(\mathrm{Ca}, \mathrm{Mg}, \mathrm{K})$ and high in soluble and exchangeable $\mathrm{Al}$ and $\mathrm{Mn}$, which are toxic to the crop (Lekwa and Whitesid 1986).

Because the soil has been subjected to long period of intermittent cropping and bush fallow, it is very low in total available nutrients. In organic fertilizer such as NPK when applied to the soil, adds nutrients, improves the soil chemical properties and enhances crop growth, development and yield (Ubi et al 2005).

Capacity of the soils often exacerbate losses of nutrients considering the importance of soil plant relationships. The objective of this study was to evaluate the chemical composition of the soil and soil reaction following $\mathrm{N}: \mathrm{P}: \mathrm{K}$ fertilizer treatment on the coastal plain sands of Akpabuyo, Nigeria.

W. Ubi, Department of science and technology, National Open University of Nigeria, Calabar Study Centre, Calabar, Nigeria

M. W. Ubi, Department of Soil Science, University of Calabar, Calabar, Nigeria

A. U. Aknanidiok. Denartment of Soil Science. I Iniversitv of Calahar. Calahar. Nineria 


\section{MATERIALS AND METHODS}

The study was conducted at Akpabuvo $\left(9^{\circ} 9^{\prime}\right.$ and $8^{\circ} 12^{\prime} \mathrm{E}, 4^{\circ} 37^{\prime}-41^{\circ} \mathrm{N}$ ) in Cross River Slate, Nigeria. The climate of the area is typical of tropical humid region with a mean annual rainfall of $3500-4000$ $\mathrm{mm}$, a mean annual temperature of $26-27^{\circ} \mathrm{C}$ and mean relative humidity of $80-90 \%$ (Akpan-Idiok, 2012). The soils of the area are formed from the Tertiary Coastal Plain Sands and the landscape rises from gently to strongly undulating in most places. The original forest vegetation has disappeared due to high population density and over cultivation of the soils. The present vegetation is typical of secondary forest. Rotational bush fallow cropping system in the area constitutes the main cropping system in the area (Akpan-Idiok, 2012).

\section{Soil sampling}

Before the start of the experiment, composite soil samples were taken at depths of $0-15 \mathrm{~cm}, 15-$ $30 \mathrm{~cm} 30-40 \mathrm{~cm}$ and $40-50 \mathrm{~cm}$. Random samples were collected with the help of a soil auger and bulked to form a composite sample. The samples were packed in a polyethylene bags and labelled appropriately. There were air-dried, ground with a wooden roller and sifted through a $2 \mathrm{~mm}$ mesh sieve for chemical analysis. Sampling was repeated at a three month-interval after application of fertilizer up to the twelfth month at the various depths mentioned above.

\section{Chemical Analysis}

Soil $\mathrm{pH}$ was determined potentriometrically in 1:2.5 soil/water ratio. Organic matter was determined by the Walkey and Black method (Allison 1965). Total N was determined by the micro-kjeldahl method (Bremer. 1965). Available $P$ was determined by the molybdenum blue colour method of Murphy and Ridey (1902) alter extracting soil with Bray P-1 extracant (Bray and Kurtz, 1945). Exchangeable bases ( $\mathrm{Ca}, \mathrm{Mg} \mathrm{K}$ and $\mathrm{Na}$ ) were extracted with $1 \mathrm{M} \mathrm{N} 1-14 \mathrm{OAC} \mathrm{p}^{\mathrm{H}} 7$ and the amounts in the extracts measured with flame photometer for $\mathrm{Na}$ and $\mathrm{K}$ while $\mathrm{Ca}$ and $\mathrm{Mg}$ were determined with Atomic absorption spectrophotometer (Model 6-105 HV/Visible Speetropliotometer Jenway, UK). Exchangeable acidity was extracted with IN KCL (Mclean, 1964), while CEC was by summation of the exchangeable cations and exchangeable acidity. Base saturation was calculated as the sum of the bases (TEB) divided by CEC.

\section{Fertilizer Rates}

The four rates of NPK 20:10:10 inorganic fertilizers were applied in the following rate:

Okg NPK ha ${ }^{-1}$

$60 \mathrm{~kg} \mathrm{NPKha}^{-1}$

$90 \mathrm{~kg} \mathrm{NPK} \mathrm{ha}^{-1}$

$120 \mathrm{~kg} \mathrm{NPKha}^{-1}$

Treatments were applied in the following order:

$A P=A t$ the beginning of the experiment

$\mathrm{H}_{4}=4$ months

$\mathrm{H}_{7}=7$ months

$H_{10}=10$ monthsSoil sampling was done at the following intervals

Soil sampling was done at the following intervals:

3 months

6 months

9 months

12 months, all fitted into a Latin square design.

\section{Statistical Analysis}

Data collected were subjected to statistical analysis involving means separation, and comparing the means using standard deviation (SD), with coefficient of variability (CV\%) as outlined Steel and Torrie (1960) were used in arriving at the deductions and conclusions.

\section{RESULTS AND DISCUSSION}

\section{Soil Reaction}

Soil reaction varied from mildly acid to medium with mean $\mathrm{pH}$ values of 5.1 at 3 months, 5.1 at 6 months, 5.7 at 9 months and 5.9 at 12 months. The acidity levels in these soils could be partly attributed to moderate rainfall and removal of bases during the process of eluviation. This acidity level rated to be moderate was earlier reported (Faji and Mohammed 2000). The soil $\mathrm{pH}$ of the area is within tolerable range for crop production. The application of $\mathrm{N}: \mathrm{P}: \mathrm{K}$ fertilizer tended to increase the $\mathrm{pH}$ values at the 12 month interval more than either 3,6 , or 9 months.

\section{Soil organic matter}

The mean soil organic matter was $1.34 \mathrm{~g} \mathrm{~kg}^{-1}$ at 3 months, $1.53 \mathrm{~g} \mathrm{~kg}^{-1}$ at 6 months, $1.55 \mathrm{~g} \mathrm{~kg}^{-1}$ at 9 months and $1.68 \mathrm{~g} \mathrm{kg"} \mathrm{at} 12$ months. The organic matter contents were moderate. The rating for organic matter (OM) contents of these soils were moderate to high having mean values of $1.34 \mathrm{~g} / \mathrm{kg}^{-1}$ at 3 months, $1.53 \mathrm{~g} / \mathrm{kg}^{-}$ ${ }^{1}$ at 6 months and $1.20 \mathrm{~g} \mathrm{~kg}^{-1}$ at 9 months and $1.86 \mathrm{~g}^{\prime} \mathrm{kg}^{-1}$ at 12 months.

The low values of organic matter at 3 months could be due to high mineralization resulting to increased microbal activities, good soil aeration and low natural organic matter returns early in the season. The high organic matter in the 12 months interval later in the season is suggested to be as a result of low mineralization due to reduced microfloral activities and poor soil aeration and drainage. It might also be possible that there was organic matter accumulation from the 3 
months to 12 months after the decomposition of dead leaves and this might have accounted for the high organic matter in the 12 months. Young (1997) elucidated that high soil organic matter status leads to improved structural stability, lower bulk density and balance between fine and coarse pores. These properties he noted to ease root penetration, resist erosion and provide the necessary nutrient for the plant.

\section{Total Nitrogen}

The total $\mathrm{N}$ ranged from 0.68 to $0.87 \%$ with a mean of $0.74 \%$, at 3 months, 0.77 to $0.89 \%$ with a mean of $0.82 \%$ at 6 months 0.76 to $0.91 \%$ with a mean of $0.82 \%$ at 9 months and 0.70 to $0.88 \%$ with a mean of $0.77 \%$ at 12 months (Tables 1,2,3, and 4). The high levels of Total $\mathrm{N}$ in these soils could be attributed to the high natural organic matter returns and mineralization of plant residue and $\mathrm{N}$ fertilizer application. Similar results were obtained by Scholes et al (1994). We consider these coastal plain soils moderately suitable for crop production (FAO, 1976).

\section{Available $\mathbf{P}$}

Available $P$ values determined by Bray $P-I$ method were moderate to high and ranged from 7.14 to $13.6 \mathrm{mg} \mathrm{kg}^{-1}$ with a mean of $9.75 \mathrm{mg} \mathrm{kg}^{-1}$ at 3 months, 12.02 to $18.78 \mathrm{mg} \mathrm{kg}^{-1}$ with a mean of $16.55 \mathrm{mg} \mathrm{kg}^{-1}$ at 6 months, 28.6 to $48.10 \mathrm{mgkg}^{-1}$ with a mean of $35.58 \mathrm{mgkg}^{-1}$ at 9 months and 11.14 to $15.12 \mathrm{mg} \mathrm{kg}^{-1}$ with a mean of $13.48 \mathrm{mg} \mathrm{kg}^{-1}$ at 12 months. Soils with $P$ values below $10 \mathrm{mg} \mathrm{kg}^{-1}$ are generally considered marginally suitable (Scholes et al (1994). The available P consistently decreased with increase in profile depth and is suggested to be due to vertical and lateral movement of $P$ in the subsurface soil which could be a characteristic of soils of sand stone parent materials. Nitrogen and $P$ are organic matter dependent, as organic matter mineralizes, these elements are released into the soils.

The application of N:P:K at the interval of 9 months in November tended to increase the $P$ content of the soil more than $P$ values obtained from either 3,6 or 12 months intervals. This implies that applied $P$ to this soil is abundantly available for plants use at the period close to the later part of the season (November) than early in the season. The available $P$ values were highest in the 9 months which suggests that there was high rate of $\mathrm{P}$ mineralization together with high inorganic available $P$ within the experimental condition. It could be suggested that the 9 months with $90 \mathrm{~kg} \mathrm{ha}^{-1}$ NPK fertilizer combination could lead to high $P$ availability within the coastal acid sand ecosystem in Akpabuyo, Nigeria.

\section{Exchangeable (Ca $\mathrm{Mg} \mathrm{K}$ and $\mathrm{Na}$ )}

The exchangeable bases ranged from 4.66 to $5.6 \mathrm{cmol}(+) \mathrm{kg}$ with a mean of $4.7 \mathrm{cmol}(+) \mathrm{kg}$ for $\mathrm{Ca}$; 1.58 to $1.80 \mathrm{cmol}(+) \mathrm{kg}$ with a mean of $1,7 \mathrm{cmol}(+) \mathrm{kg}$ for $\mathrm{Mg} ; 0.12$ to $0.15 \mathrm{cmol}(+) \mathrm{kg}$ with a mean of 0.13 cmol (+) for $\mathrm{K}$ and 0.04 to $0.07 \mathrm{cmol}(+) \mathrm{kg}$ with a mean of $0.05 \mathrm{cmol}(+) \mathrm{kg}$ for $\mathrm{Na}$ for the 3 months interval. And between 4.08 to $5.18 \mathrm{cmol}(+) \mathrm{kg}$ with a mean of 4.9 $\mathrm{cmol}(+) \mathrm{kg}$ for $\mathrm{Ca}, 0.85$ to $2.98 \mathrm{cmol}(+) \mathrm{kg}$ with a mean of $1.89 \mathrm{cmol}(+)$ for $\mathrm{Mg}, 0.08$ to $0.09 \mathrm{cmol}(+) \mathrm{kg}$ with a mean of $0.09 \mathrm{cmol}(+) \mathrm{kg}$ for $\mathrm{K}$, and 0.04 to $0.05 \mathrm{cmol}$ $(+) \mathrm{kg}$ with a mean of $0.04 \mathrm{cmol}(+) \mathrm{kg}$ for $\mathrm{Na}$ during the
6 months interval. For the 9 months interval, the values were from 0.06 to $5.76 \mathrm{cmol}(+) \mathrm{kg}$ with a mean of 5.1 $\mathrm{cmol}(+) \mathrm{kg}$ for $\mathrm{Ca} ; 0.98$ to $1.21 \mathrm{cmol}(+) \mathrm{kg}$ with a mean of $1.25 \mathrm{cmol}(+) \mathrm{kg}$ for $\mathrm{Mg} ; 0.08$ to $0.12 \mathrm{cmol}(+) \mathrm{kg}$ with a mean of $0.04 \mathrm{cmol}(+) \mathrm{kg}$ for $\mathrm{K}$; and 0.02 to $0.04 \mathrm{cmol}$ $(+) \mathrm{kg}$ with a mean of $0.04 \mathrm{cmol}(+) \mathrm{kg}$ for $\mathrm{Na}$. values for 12 month interval ranged from 4.56 to $5.88 \mathrm{cmol}(+) \mathrm{kg}$ with a mean of $5.2 \mathrm{cmol}(+) \mathrm{kg}$ for $\mathrm{Ca} ; 0.12$ to $1.31 \mathrm{cmol}$ $(+) \mathrm{kg}$ will) a mean of' $1.13 \mathrm{cmol}(+) \mathrm{kg}$ for $\mathrm{Mg}$; 0.12 lo $0.14 \mathrm{cmol}(+) \mathrm{kg}$ for a mean $0.11 \mathrm{cmol}(+)$ for $\mathrm{K}$; and 0.02 to $0.05 \mathrm{cmol}(+) \mathrm{kg}$ with a mean of $0.04 \mathrm{cmol}(+) \mathrm{kg}$ for $\mathrm{Na}$. The mean values of $\mathrm{Mg} 1.25 \mathrm{cmol}(+) \mathrm{kg}$ obtained at 9 months interval tended to be higher than all other values obtained in either 3,6 or 12 months intervals. The nutrients elements (N:P:K, $\mathrm{Ca}, \mathrm{Mg}$ ) were generally higher at the surface soil, decreasing with depth below their critical levels. This is due to the effect of annual water table fluctuations causing leaching of the nutrients down the profile, a characteristic of coastal sands. Among the exchangeable cations $(\mathrm{Ca}, \mathrm{Mg}, \mathrm{K}$, $\mathrm{Na}$ ) high $\mathrm{Mg}$ and $\mathrm{Ca}$ contents were observed and agreed with the findings of Pitty (1979) who reported that $\mathrm{Mg}$ and $\mathrm{Ca}$ are the most predominant cation in tropical soils due to their strong absorption and rapid release into the soil through mineral weathering. The low value of $\mathrm{K}$ which is below critical level, $0.2 \mathrm{cmol}(+) \mathrm{kg}$ (Kyuma et a1 1986) might be attributed to the high rainfall and leaching intensity normally often encountered in coastal plain soil. The low value of $\mathrm{Na}$ could be attribute to the selective ultra filtration of sodium chloride out of the soil solution through the roots of the plants in the study area (Chapman, 1976). The distribution of exchangeable bases did not show any definite pattern, with the profile depth during the 6 months. The surface and sub-10 surface horizons with higher $\mathrm{pH}$ values tended to have a corresponding higher exchangeable bases at 3 months intervals.

The coastal plain soil at Akpabuyo is therefore well supplied with organic matter phosphorus, nitrogen, calcium and magnesium for good crop performance in the area.

\section{Cation Exchange Capacity (CEC)}

The cation exchange capacity values were generally high, ranging from 20.25 to $34.52 \mathrm{cmol}(+) \mathrm{kg}$ with a mean of $24.30 \mathrm{cmol}(+) \mathrm{kg}^{-1}$ at 3 months, 20.01 to $34.68 \mathrm{cmol}^{(+)} \mathrm{kg}^{-1}$; with a mean of $25.1 \mathrm{cmol}^{(+)} \mathrm{kg}^{-1}$ at 6 months, 20.14 to $35.16 \mathrm{cmol}(+) \mathrm{kg}^{-1}$; with a mean of $25.40 \mathrm{cmol}(+) \mathrm{kg}^{-1}$ at 9 months and 22.96 to $37.29 \mathrm{cmol}$ $(+) \mathrm{kg}^{-1}$; with a mean of $27.41 \mathrm{cmol}^{(+)} \mathrm{kg}^{-1}$ at 12 months, (Tables 1,2,3 and 4).

The CEC values for the 12 months interval, on the average, was $7.3 \%$ higher than those of either 3,6 , or 9 months. The soils had CEC value above $20 \mathrm{cmol}(+) \mathrm{kg}^{-1}$ regarded as suitable for crop production if other factors are favourable (FAO 1976).

\section{Base Saturation (\% BS)}

- The \% B.S ranged between 57.8 and $64.1 \%$ with a mean of $58.2 \% ; 58.2$ to $69.6 \%$ with a mean of $62.6 \% ; 30.1$ to $67.2 \%$ with a mean of $58.4 \%$ and 66.2 to $67.6 \%$ with a mean of $64.7 \%$ for the $3,6,9$ and 12 
- Months intervals respectively. The \% B.S determined at 6 and 12 months intervals were close and higher than values of 3 and 9 months and exceeded the critical limit of $60 \%$ established for the ecological zone (Hollan et al 1989).

\section{Exchange acidity $\left(\mathrm{Al}\right.$ and $\left.\mathrm{H}^{+}\right)$}

Exchangeable Al ranged between 5.6 and 35.3 cmol (+) $\mathrm{kg}^{-1}$ with a mean of $30.3 \mathrm{cmol}(+) \mathrm{kg}^{-1}$ at 3 months, 19.6 to $27.4 \mathrm{cmol}(+) \mathrm{kg}^{-1}$, with a mean of 23.3 $\mathrm{cmol}(+) \mathrm{kg}^{-1}$ at 6 months 10.3 to $21.3 \mathrm{cmol} ;(+) \mathrm{kg}^{-1}$, with a mean of $15.3 \mathrm{cmol}(+) \mathrm{kg}^{-1}$ at 9 months and $8.6+18.6$ cmol (+) $\mathrm{kg}^{-1}$; with a mean of $13.2 \mathrm{cmol}(+) \mathrm{kg}^{-1}$ at 12 months. There was a marked decrease in exchangeable acidity with increasing intervals from 9 to 12 months. This means that Al toxicity was very likely to occur later in the season (Raji and Mohammed 2000). The toxicity of soluble Al may be mitigated in part by an increase in the soluble Ca concentration (Jackson 1969, Foy et al, 1978; Helyar, 1978).

The values of $\mathrm{pH}$ ranged from 12.4 to $13.0 \mathrm{cmol}$ $(+) \mathrm{kg}^{-1}$ with a mean of $12.3 \mathrm{cmol}(+) \mathrm{kg}^{-1}$ at 3 months, 0.2 to $16.2 \mathrm{cmol}(+) \mathrm{kg}^{-1}$; with a mean of $13.1 \mathrm{cmol}(+)$ $\mathrm{kg}^{-1}$ at 6 months 7.1 to $13.0 \mathrm{cmol}(+) \mathrm{kg}^{-1}$; with a mean of $9.8 \mathrm{cmol}^{(+)} \mathrm{kg}^{-1}$ at 9 months and 5.1 to $9.1 \mathrm{cmol}^{(+)} \mathrm{kg}^{-1}$ with a mean of $6.6 \mathrm{cmol}(+) \mathrm{kg}^{-1}$ at 12 months. There was a gradual drop in the values of $\mathrm{H}^{+}$later in the season. However, the exchange complex for the 3 and 6 months were dominated by $\mathrm{H}^{+}$and because of the preponderance of $\mathrm{H}^{+}$ions in the exchange complex, the clays of this humid region appeared to have calciumhydrogen complex. In this case, $\mathrm{H}^{+}$ions may displace metallic ions giving rise to an acid (hydrogen saturated) clay. Acid clays are calcium aluminum clays. The indirect negative fertility effect of leaching $\mathrm{Ca}$ and $\mathrm{Mg}$ is the rise in the level of exchangeable $\mathrm{Al}+\mathrm{H}$ which is a reflection of acidic soil (Lekwa and Whiteside 1986).

Table 1: Nutrient distribution within different soil depths at 3 months

\begin{tabular}{|c|c|c|c|c|c|c|c|c|c|c|c|c|}
\hline Properties & $\mathrm{Sd}$ & $\frac{0}{x}-15$ & $\begin{array}{l}\text { CV } \\
(\%)\end{array}$ & $\mathrm{Sd}$ & $\frac{15-30}{x}$ & $\begin{array}{l}\text { CV } \\
(\%)\end{array}$ & Sd & $\frac{30-40}{x}$ & $\begin{array}{l}\text { CV } \\
(\%)\end{array}$ & $\mathrm{Sd}$ & $\begin{array}{ll}40 & - \\
50 & \\
\bar{x} & \end{array}$ & $\begin{array}{l}\text { CV } \\
(\%)\end{array}$ \\
\hline $\mathrm{pH}\left(\mathrm{H}_{2} \mathrm{O}\right)$ & 0.02 & 0.2 & 0.02 & 0.02 & 5.3 & 0.3 & 0.03 & 4.9 & 0.5 & 0.10 & 4.8 & 1.6 \\
\hline $\mathrm{Na}(\mathrm{cmol} \mathrm{kg})$ & 0.02 & 0.06 & 0.04 & 0.10 & 0.05 & 8.2 & 0.12 & 0.05 & 4.5 & 0.02 & 0.03 & .8 \\
\hline $\mathrm{K}(\mathrm{cmol} \mathrm{kg})$ & 0.02 & 0.06 & 5.1 & 0.10 & 0.04 & 18.1 & 0.10 & 0.04 & 3.8 & 0.02 & 0.03 & 2.4 \\
\hline $\mathrm{Ca}(\mathrm{cmol} \mathrm{kg})$ & 0.07 & $>.16$ & 8.9 & 0.04 & 5.03 & 15.4 & 0.05 & 4.01 & 17.2 & 0.02 & 4.66 & 0.6 \\
\hline $\mathrm{Mg}(\mathrm{cmol} \mathrm{kg})$ & 0.03 & 0.87 & 3.1 & 0.50 & 0.84 & 24.3 & 0.32 & 0.81 & 6.8 & 0.50 & 0.81 & 4.9 \\
\hline Exch. Al. & 0.10 & 35.3 & 2.8 & 0.14 & 31.6 & 28.1 & 0.14 & 28.70 & 21.2 & 0.30 & 25.5 & 2.4 \\
\hline Acidity $\mathrm{H}^{\mathrm{t}}$ & 0.10 & 13.0 & 2.1 & 0.32 & 12.4 & 15.6 & 0.10 & 1.10 & 7.2 & 0.02 & 1.0 & 3.0 \\
\hline $\begin{array}{l}\text { Organic matter } \\
(\%)\end{array}$ & 0.02 & 1.82 & 3.4 & 0.12 & 1.24 & 7.4 & 0.10 & 1.21 & 8.5 & 0.30 & 1.08 & 3.1 \\
\hline P. available & 0.32 & 13.64 & 4.2 & 0.10 & 11.86 & 9.2 & 0.15 & 8.36 & 11.9 & 0.10 & 7.14 & 6.3 \\
\hline CEC (cmol kg) & & 34.52 & 10.5 & 0.32 & 22.24 & 0.4 & 0.32 & 20.15 & 10.4 & 0.30 & 20.25 & 5.8 \\
\hline Total N & 0.03 & 0.87 & 06 & 0.12 & 0.81 & 16.7 & 0.10 & 0.73 & 18.1 & 0.30 & 0.68 & 2.7 \\
\hline B (\%) & 0.031 & 64.1 & 6.5 & 0.10 & 58.7 & 14.1 & 0.31 & 58.30 & 7.5 & 0.02 & 51.8 & 12.6 \\
\hline $\begin{array}{l}\frac{S d}{X} \\
C V\end{array}$ & Jord & ation & & & & & & & & & & \\
\hline
\end{tabular}


Table 2: Nutrient distribution within different soil depths at 6 months

\begin{tabular}{|c|c|c|c|c|c|c|c|c|c|c|c|c|}
\hline Properties & $\mathrm{Sd}$ & $\frac{0}{x}-15$ & $\begin{array}{l}\text { CV } \\
(\%)\end{array}$ & Sd & $\begin{array}{l}15-30 \\
\bar{x}\end{array}$ & $\begin{array}{l}\text { CV } \\
(\%)\end{array}$ & Sd & $\begin{array}{l}30-40 \\
\bar{x}\end{array}$ & $\begin{array}{l}\text { CV } \\
(\%)\end{array}$ & Sd & $\begin{array}{ll}40 & - \\
50 & \\
\bar{x} & \end{array}$ & $\begin{array}{l}\text { CV } \\
(\%)\end{array}$ \\
\hline $\mathrm{pH}\left(\mathrm{H}_{2} \mathrm{O}\right)$ & 0.02 & 5.17 & 0.6 & 0.02 & 5.13 & 0.3 & 0.02 & 5.109 & 0.6 & 0.10 & 5.04 & 1.5 \\
\hline $\mathrm{Na}(\mathrm{cmol} \mathrm{kg})$ & 0.02 & 0.05 & 0.8 & 0.10 & 0.05 & 15.2 & 0.10 & 0.04 & 15.4 & 0.02 & 0.04 & 2.4 \\
\hline $\mathrm{K}(\mathrm{cmol} \mathrm{kg})$ & 0.10 & 0.09 & 6.5 & 0.04 & 0.12 & 21.0 & 0.10 & 0.08 & 24.1 & 0.02 & 0.08 & 15.7 \\
\hline $\mathrm{Ca}(\mathrm{cmol} \mathrm{kg})$ & 0.06 & 5.18 & 3.6 & 0.04 & 5.27 & 14.3 & 0.04 & 4.91 & 15.9 & 0.02 & 4.08 & 0.6 \\
\hline $\mathrm{Mg}(\mathrm{cmol} \mathrm{kg})$ & 0.07 & 2.90 & 21.2 & 0.02 & 1.95 & 16.1 & 0.02 & 1.77 & 12.6 & 0.10 & 0.85 & 4.8 \\
\hline Exch. Al. & 0.10 & 22.4 & 12.9 & 0.02 & 25.0 & 22.6 & 0.50 & 21.4 & 31.0 & 0.10 & 19.6 & 25.6 \\
\hline Acidity $\mathrm{H}^{\mathrm{t}}$ & 0.10 & 16.0 & 2.5 & 0.14 & 13.8 & 14.2 & 0.17 & 12.6 & 0.4 & 0.30 & 10.2 & 3.0 \\
\hline Organic matter (\%) & 0.10 & 2.13 & 2.1 & 0.50 & 1.50 & 25.5 & 0.60 & 1.34 & 12.6 & 0.02 & 1.15 & 0.2 \\
\hline P. available & 0.32 & 18.98 & 2.0 & 0.60 & 18.24 & 0.4 & 0.14 & 17.17 & 10.0 & 0.30 & 12.02 & 6.3 \\
\hline CEC (cmol kg) & 0.04 & 34.68 & 2.5 & 0.17 & 23.35 & 12.5 & 0.02 & 22.13 & 8.5 & 0.10 & 20.1 & 5.1 \\
\hline Total N & 0.02 & 0.89 & 2.6 & 0.18 & 0.56 & 1.7 & 0.04 & 0.81 & 6.2 & 0.10 & 0.77 & 0.4 \\
\hline B (\%) & 0.10 & 62.0 & 13.2 & 0.04 & 59.6 & 2.5 & 0.03 & 54.5 & 4.3 & 0.02 & 52.2 & 0.6 \\
\hline $\begin{array}{l}\frac{S d}{X} \\
C V(\%)\end{array}$ & & dard & & & & & & & & & & \\
\hline
\end{tabular}

Table 3: Nutrient distribution within different soil depths at 9 months

\begin{tabular}{|c|c|c|c|c|c|c|c|c|c|c|c|c|}
\hline Properties & $\mathrm{Sd}$ & $\frac{0}{x}-15$ & $\begin{array}{l}\text { CV } \\
(\%)\end{array}$ & Sd & $\frac{15-30}{\bar{x}}$ & $\begin{array}{l}\text { CV } \\
(\%)\end{array}$ & $\mathrm{Sd}$ & $\begin{array}{l}30-40 \\
\bar{x}\end{array}$ & $\begin{array}{l}\text { CV } \\
(\%)\end{array}$ & Sd & $\begin{array}{ll}40 & - \\
50 & \\
\bar{x} & \end{array}$ & $\begin{array}{l}\text { CV } \\
(\%)\end{array}$ \\
\hline $\mathrm{pH}\left(\mathrm{H}_{2} \mathrm{O}\right)$ & 0.02 & 5.79 & 0.04 & 0.10 & 5.66 & 0.5 & 0.02 & 5.64 & 0.6 & 0.10 & 5.52 & 0.4 \\
\hline $\mathrm{Na}(\mathrm{cmol} \mathrm{kg})$ & 0.02 & 0.04 & 0.06 & 0.10 & 0.04 & 0.8 & 0.02 & 0.03 & 2.8 & 0.10 & 0.02 & 0.6 \\
\hline $\mathrm{K}(\mathrm{cmol} \mathrm{kg})$ & 0.10 & 0.12 & 6.4 & 0.02 & 0.10 & 5.8 & 0.02 & 0.08 & 10.5 & 0.02 & 0.08 & 6.5 \\
\hline $\mathrm{Ca}(\mathrm{cmol} \mathrm{kg})$ & 0.02 & 5.76 & 3.8 & 01.0 & 5.68 & 2.9 & 0.02 & 4.97 & 8.1 & 0.10 & 4.06 & 3.9 \\
\hline $\mathrm{Mg}(\mathrm{cmol} \mathrm{kg})$ & 0.02 & 1.21 & 4.5 & 0.10 & 1.35 & 5.1 & 0.10 & 1.62 & 6.2 & 0.10 & 0.98 & 2.6 \\
\hline Exch. Al. & 0.30 & 21.3 & 22.8 & 0.30 & 18.0 & 24.2 & 0.32 & 12.1 & 20.9 & 0.30 & 10.3 & 30.2 \\
\hline Acidity $\mathrm{H}^{\mathrm{t}}$ & 0.31 & 13.0 & 28.2 & 0.30 & 10.8 & 21.8 & 0.30 & 0.6 & 24.3 & 0.32 & 0.3 & 24.2 \\
\hline Organic matter (\%) & 0.10 & 2.14 & 4.5 & 0.10 & 1.54 & 6.2 & 0.10 & 1.33 & 5.4 & 0.02 & 1.20 & 8.0 \\
\hline P. available & 0.32 & 43.10 & 2.6 & 0.02 & 36.31 & 3.0 & 0.02 & 34.32 & 3.8 & 0.10 & 28.60 & 5.6 \\
\hline CEC $(\mathrm{cmol} \mathrm{kg})$ & 0.10 & 35.16 & 2.1 & 0.02 & 24.12 & 2.5 & 0.32 & 22.00 & 2.9 & 0.02 & 20.14 & 3.9 \\
\hline Total N & 0.10 & 36.4 & 2.5 & 0.02 & 30.5 & 2.6 & 0.02 & 30.0 & 3.6 & 0.02 & 20.3 & 2.7 \\
\hline B (\%) & 0.02 & 0.91 & 3.0 & 0.10 & 0.86 & 2.8 & 0.10 & 0.80 & 2.4 & 0.02 & 0.76 & 2.4 \\
\hline $\begin{array}{l}\frac{S d}{X} \\
C V(\%)\end{array}$ & & & & & & & & & & & & \\
\hline
\end{tabular}


Table 4: Nutrient distribution within different soil depths at 12 months

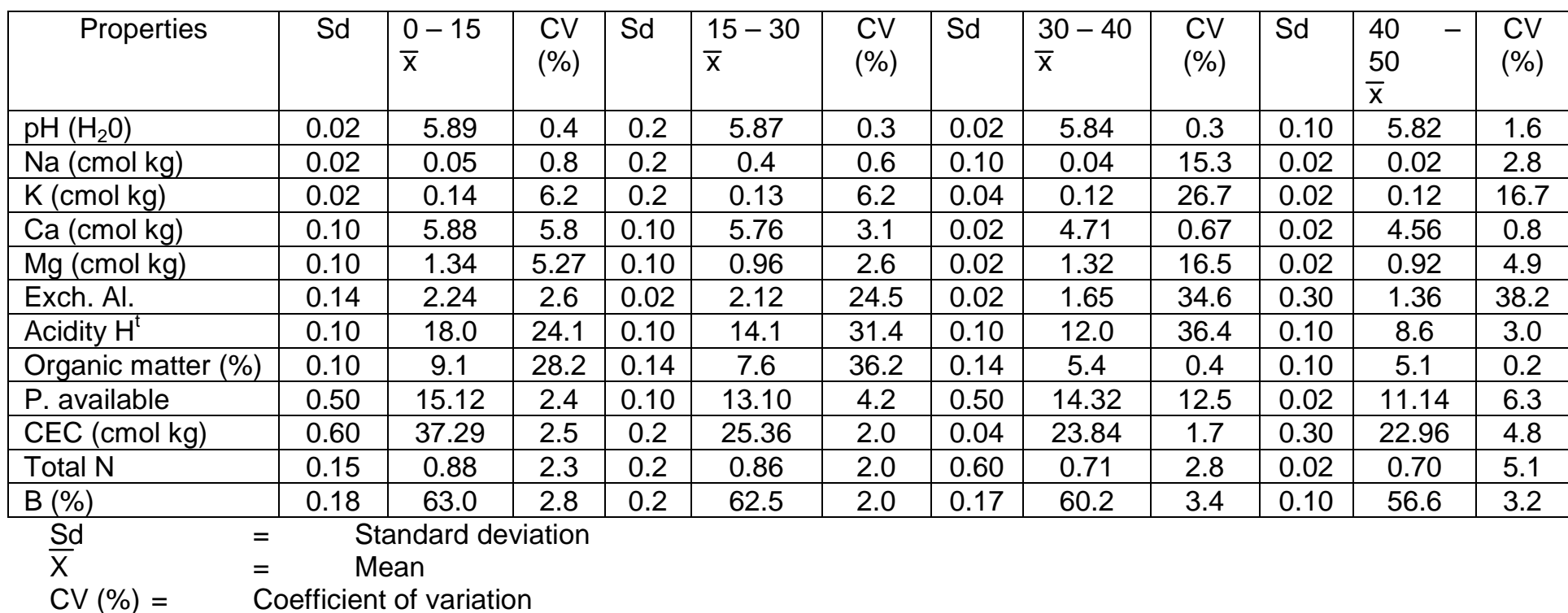

\section{CONCLUSION}

The study $x$-rayed soils fertility indices such as $\mathrm{pH}$, Organic matter. Cation Exchange Capacity, Total Nitrogen, Exchangeable bases, Available P, Exchangeable Acidity and percent Base saturation as influenced by treatment combination in the soil. Though characterized by low $\mathrm{K}$ and high percentage aluminum saturation, their agricultural utilization is potentially high if proper soil management practices are adopted.

\section{REFERENCES}

Agboola A. A. and Gorea R. B., 1973. The Relationship between Sol $\mathrm{pH}$, organic matter available $\mathrm{P}$, exchangeable potassium, calcium, magnesium and nine elements in the maize tissue Soil Sci. 15:367:375.

Allison, L. E., 1965. Organic Carbon in C.A Black (cd) Methods ol' Soil Analysis. Ayron 9 ASA, Madison Wisconsin, USA.

Akpan-Idiok, A. U., 2012. Physicochemical properties, degradation rate and vulnerability potential of soils formed on coastal plain sands in Southeast, Nigeria. International Journal of Agricultural Research. 7(7); 358 - 366.

Bremner, J. M., 1965. Total Nitrogen, 1NCA Black (ed) Methods of Soil Analysis part 2. American Society of Agronomy, Madison W. 1. Agronomy. 9:1149-1198.

Bray, R. H. and Kurtz, L. T., 1945. Determination of Total and Available forms of Phosphorus in Soils. Soil Science Society of America 54:39-45.
Chapman, V. J., 1976. Mangrove vegetation, Gramer, New York.

Enwesor, E. G., 1981. Fertility status and productivity of acid sands. In acid soils of Southern Nigeria, monograph No. 1 Soil Science Society Nigeria pp 56-73.

Faji B. A. and Mohammed A., 2000. Nature of Soil Acidity in Nigerian Savanna. Savanna Journal of Agriculture Research 15:15-24.

F.A.O., 1986. Soil Map of the World. Revised Legend World Soil Resource, Report 60, FAO Rome.

F.A.O., 1976. Frame work of Land Evaluation, FAO Soils Bulletin 32, Rome FAO.

Foy, C. D. Burns, G. R. Brown, J. C. and Fleming A. L., 1978. Differential A13t tolerance' of two wheat varieties associated with plant and use of $\mathrm{pH}$ charges around their roots. Sols Science Society. American Proc. 29:64-67.

Helyak K. R., 1978. Effect of aluminum and manganese toxicity on legume growth. 207-231. Inc. SAndrew and li J. Kampralh (ed) Mineral nutrition of legumes in tropical and sub-tropical soils $\mathrm{C}$. SIRO, Meboune. Australia.

Holland M. D. Alien, R. K. Barton G and Murphy S. T., 1989. Land Evaluation and Agricultural Recommendations. Cross River State National Park, Oban Division p. 118.

Holland M. D. Alien, V. G., Barton D and Murphy S. T., 1989. Land Evaluation and Agricultural Recommendations. Cross River State National Park, Oban Division. Prepared by ONDRI in collaboration with WWF for Federal Republic of Nigeria and Cross River State. 
Jackson, M., 1996. Soil Chemical Analysis Course, $2^{\text {nd }}$ ed Dept of soil science, University of Wisconson, USA.

Kyuma, K. losaki T. and Juo, A. S. R., 1986. Evaluation of the soils. In ASR Juo and Low (ed) the wetland soil and rice. In sub-Sahara Africa. Proceedings. In international conference of wetland soil utilization for rice production in subSahara Africa.

Lekwa, G. and Whiteside F. P., 1986. Coastal plain sands of South Eastern Nigeria. 11 Forms of extractable Iron, aluminum and phosphorus. Soil Sci. Soc. American Journal. 50:156-166.

Mclean, E. O., 1964. Aluminum. In Methods of Soil Analysis (ed C. A. Black) pp. 978-998. Agron No. 9. Part 2 America Soc. Agronomy Madison, Wisconson.

Murphy J. and Riley P., 1962. Modified single solution method for the Determination of phosphorus in

Natural Waters. Annals Chem. Act 27:31-36.

Nye, P. H. and Berthenx, T., 1969. The distribution of phosphorus in forest and savanna soils of Gold Coast and its agricultural significance. Journal Agricultural Science 48:141-159.

Pitty, A. F., 1979. Geography and Soil Properties, Methuen and Company Ltd Oxford.
Russel, E. W., 1973. Soil Conditions and Plant Growth. Longman group Ltd. London pp. 752-753.

Scholes, R. Datal J. and Singer., 1994. Soil Physics and Fertility. The effect of water, temperature and texture in P. L. Woomer and M. J. Swift (eds). The biological management of tropical soil fertility. WileySayee Publications pp. 136-177.

Soil Survey Staff., 1981. Estimation and description of soils in the field. In soil survey manual USDA Agric handbook 18. Us Government Printing Office, Washington DC.

Steel R. H. D. and Torrie J. H., 1960. Principles and procedure of statistics. McGraw Hill Book Company, New York.

Udo, E. J. Ogunwale, J. A. and Salem, M. A., 1981. Characteristics of five Nigerian soil profiles developed on Coastal Plain Sands. Nig Journal of Soil Science 12:54-70.

Young, A., 1997. Soil organic matter and physical properties. Agro Forestry for soil management $2^{\text {nd }}$ edition. CAB Inlemalional. Willinlbrd, UK. Pp 98-109.

Ubi, W. H. lqwe, S. Ekpe and Otu Ibor., 2005. Preliminary trial of fertilizer types on pineapple (Ananas Comosus) grown in coastal acid sands of Cross River State Nigeria. Global Journal, of Pure and Applied Science Vol. 11 No 4: 457460. 